\title{
A Review on the Management of Biliary Complications after Orthotopic Liver Transplantation
}

\author{
Brian T. Moy and John W. Birk* \\ Department of Medicine, Division of Gastroenterology-Hepatology, University of Connecticut Health Center, Farmington, CT, USA
}

\begin{abstract}
Orthotopic liver transplantation is the definitive treatment for end-stage liver disease and hepatocellular carcinomas. Biliary complications are the most common complications seen after transplantation, with an incidence of $10-25 \%$. These complications are seen both in deceased donor liver transplant and living donor liver transplant. Endoscopic treatment of biliary complications with endoscopic retrograde cholangiopancreatography (commonly known as ERCP) has become a mainstay in the management post-transplantation. The success rate has reached $80 \%$ in an experienced endoscopist's hands. If unsuccessful with ERCP, percutaneous transhepatic cholangiography can be an alternative therapy. Early recognition and treatment has been shown to improve morbidity and mortality in post-liver transplant patients. The focus of this review will be a learned discussion on the types, diagnosis, and treatment of biliary complications post-orthotopic liver transplantation.
\end{abstract}

Citation of this article: Moy BT, Birk JW. A review on the management of biliary complications after orthotopic liver transplantation. J Clin Transl Hepatol 2019;7(1):61-71. doi: 10.14218/JCTH.2018.00028.

\section{Introduction}

Biliary tract complications are often seen in liver transplantation recipients and account for a major cause of morbidity and mortality in post-transplant patients. Common complications are anastamotic strictures (AnS), non-anastamotic strictures (NAnS), bile leaks, bile duct stones, bile casts, bilomas, mucoceles, and hemobilia (Table 1$) \cdot{ }^{1-4}$ Bile duct complications often depend upon the type of transplant performed, either deceased donor or living donor liver transplant (DDLT and LDLT, respectively), the number of bile ducts involved,

Keywords: Biliary tract complication; Orthotropic liver transplantation; Stricture; Bile leak.

Abbreviations: AnS, anastamotic strictures; CBD, common bile duct; DDLT, deceased donor liver transplant; ERCP, endoscopic retrograde cholangiopancreatography; fcSEMS, fully covered self-expanding metal stent; LDLT, living donor liver transplant; MRCP, magnetic resonance cholangiopancreatography; NAnS, non-anastamotic strictures; OLT, orthotopic liver transplantation; PTC, percutaneous transhepatic cholangiography; SEMS, self-expanding metal stent; US, ultrasound.

Received: 18 April 2018; Revised: 23 September 2018; Accepted: 29 October 2018

* Correspondence to: John W. Birk, Department of Medicine, Division of Gastroenterology-Hepatology, University of Connecticut Health Center, Farmington, CT 06030, USA. E-mail: birk@uchc.edu and the anastomosis chosen by the surgeon (choledochocholedochotomy or hepaticojejunostomy). ${ }^{1}$

Early identification and quick treatment of recognized biliary complications following transplant have been shown to reduce morbidity and mortality, and to improve graft survival. ${ }^{1}$ Overall, endoscopic retrograde cholangiopancreatography (ERCP) therapy is safe post-liver transplant and has a high success rate. ERCP complication rates of $5-9 \%$ post-orthotropic liver transplantation (OLT) are similar to non-transplant ERCP. ${ }^{5-9}$ There is an estimated 2-times to 3-times increased incidence of biliary complications in LDLT compared to DDLT.

Biliary complications can be organized as early (within 4 weeks) or late (after 4 weeks), and this should frame the practitioner's thinking (Table 2). However, since biliary complications based on timelines can be ambiguous, we based this review on occurrence frequency. The aim of this review is to go through how to recognize, diagnose, and treat biliary complications post-OLT with the most up-to-date research.

\section{Biliary strictures}

Forty percent of post-transplant biliary complications are from bile duct strictures. ${ }^{10}$ AnS account for $80 \%$ of all strictures, and NAnS account for about $20 \% .{ }^{10}$ AnS are more commonly seen after LDLT than DDLT because LDLT anastomoses are made between multiple small peripheral bile ducts. ${ }^{1}$ AnS that occur early after OLT are often due to surgical issues, whereas late AnS could be from primary ischemia with poor healing. ${ }^{11,12}$

It is generally accepted that strictures of all types are more prevalent with Roux-en-Y choledochojejunostomy, but some contest this. ${ }^{4,13}$ Long-term biliary complications between duct-to-duct and Roux-en-Y surgeries are comparable in review of the literature. ${ }^{4,14-17}$ Grief et al. ${ }^{4}$ showed a higher incidence of post-transplant strictures with Roux-en-Y choledochojejunostomy. However, 1 year after transplant, the incidence of biliary strictures decreases to around $4 \% .{ }^{18}$ There is also an increased risk for bile leaks if an AnS is present due to increases in biliary pressure. ${ }^{19,20}$

AnS usually occur in the first 12 months, and are single, shorter, and within $5 \mathrm{~mm}$ of the anastomotic site. ${ }^{1}$ The pathophysiological events can be multifactorial, such as inadequate mucosa at an anastomotic site, local tissue ischemia, localized edema, and fibrosis occurring at the site of healing. ${ }^{3,5,14}$ Early identification of the stricture correlates with a better response to short-term stenting (3-6 months). ${ }^{21}$ AnS within 3 months of transplant have been shown to have the best prognosis. ${ }^{22}$ After 12 months, AnS have a poorer response to stent and dilatation while relapse rate is high, at $30-40 \% .^{22}$ 
Moy B.T. et al: Biliary complications after OLT

Table 1. Biliary Complications after liver transplantation ${ }^{93}$

\begin{tabular}{lll}
\hline Biliary complication & Risk factor & $\begin{array}{c}\text { Incidence after liver } \\
\text { transplantation }\end{array}$ \\
\hline Anastomotic stricture & $\begin{array}{l}\text { Ischemia, reperfusion injury, duct-to-duct anastomosis, } \\
\text { and type of transplant }\end{array}$ & $6-12 \%$ \\
Non-anastomotic stricture & Hepatic artery thrombosis, cold ischemia time & $0.5-10 \%$ \\
Biloma & Hepatic artery ischemia, bile duct necrosis, ruptured bile duct & $2.6-11.5 \%$ \\
Bile leak & Anastomosis type, PTC tube tract, excessive use of electrocautery, & $8 \%$ \\
Stones, sludge, clots & cut of liver intraoperatively & $5 \%$ \\
Biliary cast syndrome & Stricture, ischemia, infections & $2.5-3 \%$ \\
Hemobilia & Hepatic artery stenosis and stricture & $1 \%$ \\
Mucocele & PTC or biopsy & Rare \\
\hline
\end{tabular}

Abbreviation: PTC, percutaneous transhepatic cholangiography.

\section{Diagnosis of anastomotic strictures}

Biliary complications are often diagnosed in asymptomatic OLT recipients based on elevated liver function markers, including: aspartate aminotransferase/alanine aminotransferase, alkaline phosphatase, and gamma-glutamyltransferase. Clinically, patients may present with signs of cholangitis, including: fever, abdominal pain, jaundice, and confusion. The initial evaluation should include liver function tests and an ultrasound (US) with Doppler. These tests will help to evaluate the vasculature, to rule-out hepatic artery thrombosis.

Although a rare cause for biliary strictures, hepatic artery thrombosis is an emergency situation post-OLT and often results in graft failure. Hepatic artery thrombosis can be detected on US with Doppler, with a sensitivity of $91 \%$ and specificity of $99 \% .^{23}$ If vascular obstruction is suspected on Doppler US, hepatic angiography can be considered to confirm the findings. US is also used in evaluation for biliary obstruction, with a sensitivity of $38-66 \% .{ }^{18,24}$ The absence of bile duct dilation should not prevent further investigation if suspicion is high for biliary tract complication.

If the suspicion is high for biliary tract complication, along with an US that shows bile duct obstruction, a cholangiogram by ERCP or percutaneous transhepatic cholangiography (PTC) should be the next step (see below for magnetic resonance cholangiopancreatography (MRCP) utility in this evaluation). ${ }^{3,5,6,25-28}$ Liver biopsy can often reveal impaired bile flow suggestive of a biliary complication, but it is not always

Table 2. Timing of biliary complications after liver transplantation

\begin{tabular}{ll}
\hline $\begin{array}{l}\text { Early complications } \\
(<4 \text { weeks })\end{array}$ & $\begin{array}{l}\text { Late complications } \\
(>4 \text { weeks })\end{array}$ \\
\hline $\begin{array}{l}\text { Hemobilia, bile leaks, } \\
\text { biloma }\end{array}$ & $\begin{array}{l}\text { Biliary clots, biliary } \\
\text { cast syndrome, } \\
\text { stones, and sludge }\end{array}$ \\
$\begin{array}{l}\text { Anastomosis necrosis } \\
\text { and anastomotic stricture }\end{array}$ & $\begin{array}{l}\text { Anastomotic and } \\
\text { non-anastomotic stricture } \\
\text { Roux-en-Y torsion }\end{array}$ \\
& $\begin{array}{l}\text { Redundant common bile } \\
\text { duct, mucocele }\end{array}$ \\
\hline
\end{tabular}

apparent. Furthermore, liver biopsy can be performed in the acute setting to rule-out rejection or recurrence of hepatitis $C$.

In recent years, MRCP has gained more acceptance given the non-invasive nature of the technique and its ability to map out the biliary anatomy. MRCP has a sensitivity of $93-96 \%$ and specificity of $90-94 \%$ for diagnosing biliary obstruction. ${ }^{12,29}$ An MRCP is a good non-invasive alternative option for further investigation of the biliary tree when there is lower suspicion for a biliary complication. Its main disadvantage is the low sensitivity when looking for leaks, sludge, or small stones $(<5 \mathrm{~mm}){ }^{30}$

The decision to proceed with ERCP or PTC often depends on the biliary surgery performed at time of transplant. In patients with duct-to duct anastomosis, ERCP has been shown to be the test of choice when diagnosing and providing an intervention for a biliary complication. ${ }^{14}$ PTC is used when ERCP has been unsuccessful or in patients with Roux-en-Y choledochojejunostomy. In the subset of patients with a Roux-en-Y surgery, ERCP can be attempted using a balloon enteroscopy or with surgical assistance to access the small bowel for cannulation. If either PTC or ERCP can only provide diagnostic information but are therapeutically unsuccessful, Roux-en-Y choledochojejunostomy is a rescue surgical technique, with a 5-year survival rate at approximately $70 \% .^{5,11}$

It is important to have an understanding of the different types of reconstruction that occur during OLT when evaluating a patient with a potential biliary complication. An end-to-end choledococholedocal anastomosis is the preferred surgery at most institutions. ${ }^{4}$ This method preserves the sphincter of Oddi and the connection between the biliary and enteral system, thus allowing access if needed with ERCP. Rouxen-Y is the other alternative surgery performed if there is underlying biliary disease, like in primary sclerosing cholangitis or if the bile ducts differ in size. ${ }^{29}$ With LDLT, the living donor's right or left lobe is transplanted, which makes intrahepatic ductal anastomosis more difficult to achieve because of the nature of the small caliber ducts. ${ }^{30}$

Other than surgery type, risk factors for strictures include bile leak, hepatic artery thrombosis, hepatic artery stenosis, dissection of periductal tissue during procurement, use of electrocautery for biliary duct bleeding, and tension of the duct anastomosis. In an attempt to better hold the primary biliary anastomosis, a surgeon may use non-absorbable 
sutures. These sutures can then form a focus, called a surgical knot. The surgical knot can obstruct or migrate into the lumen, causing biliary complications. Additional risks for anastomotic strictures include different duct sizes between donor and recipient, ischemic injury, $A B O$ incompatibility, cytomegalovirus infection, cold and warm ischemia times, recipient's and donor's age, prior liver dysfunction in the recipient, donation after cardiac death, and primary sclerosing cholangitis, and all can contribute to an AnS biliary stricture. ${ }^{5,12,15-18,28,31-38}$

A T-tube is often placed across the biliary anastomosis during surgery, with the long limb of the " $T$ " draining externally and allowing the flow of bile both into the intestine and into the drain after surgery. ${ }^{39}$ Placement of a T-tube postliver transplant is associated with a higher incidence of biliary complications, such as strictures, bile leaks, and cholangitis. ${ }^{19,40-43} \mathrm{~A}$ meta-analysis looking at six randomized controlled trials showed no benefit with T-tube placement. ${ }^{20}$ T-tube placement for duct reconstruction in DDLT patients has shown a decreased incidence of AnS; however, this feature has come at the cost of an increased risk for biliary leakage after removal of the T-tube, which is reported to be $5-33 \% .44$ One advantage of the T-tube is the ability to perform direct cholangiography easily with the tube in place. ${ }^{39} \mathrm{~T}$ tube-placement in liver transplant is controversial and more studies need to be done on its efficacy overall and in specific situations.

\section{Management of AnS}

The mainstay of anastomotic stricture management revolves around ERCP therapy. Most patients will require multiple ERCP sessions every 3 months, with stenting and dilation for 1-2 years. Typically, a guidewire is placed across the stricture, dilated with $6-8 \mathrm{~mm}$ balloons and then one or multiple 7 to $11.5 \mathrm{Fr}$ plastic stents are placed. Historically, some endoscopists have proceeded with dilation alone, which has been shown to be less effective than combined dilation with periodic stenting. ${ }^{1,3,18,23}$ In a head-to -head study, combination therapy was more effective than balloon dilation alone in 24 patients. ${ }^{45,46}$ In another retrospective study, dilate/stent therapy was also more effective than balloon dilation alone $(88 \%$ vs. $37 \%) .{ }^{45}$ In a systematic review by Kao et al. ${ }^{47}$, the average number of ERCP sessions for AnS is 2.7 to 5.4 , with placement of 1.9 to 2.5 stents with each ERCP.

Plastic stents should be exchanged every 3 months to avoid occlusion causing cholangitis. In a review of 440 transplanted patients with AnS treated by plastic stents during $E R C P$, the resolution rate was $85 \%$. Rate of recurrence depended on duration of stenting. Less than 12 months of stenting had a $78 \%$ stricture resolution rate, while $>12$ months had a $97 \%$ resolution rate. ${ }^{47}$ Tabibian et al. ${ }^{48}$ looked at 83 patients with AnS 20 months after OLT. Sixtynine strictures were treated, with 65 (94\%) strictures achieving resolution over 15 months. Increasing the number of stents has shown to improve success. In the group that successfully completed treatment, a total of 8 stents were used, with an average of 2.5 stents per ERCP. In the group with incomplete resolution of AnS, a total of 3.5 stents were placed. ${ }^{48}$ Costamagna et al. ${ }^{49}$ recommends balloon dilation followed by placement of maximum number of $10 \mathrm{Fr}$ stents, and repeating ERCP every 3 months with stent stacking until complete resolution of the stricture on fluoroscopy. That study showed $80-95 \%$ success, with $20-35 \%$ recurrence.
In another series, the approach of placing a maximum number of stents with exchanges at 3 months had yielded a $90-94 \%$ success rate. 48,49

Temporary placement of a fully covered self-expanding metal stent (fCSEMS) has been looked at for AnS to try and reduce the number of ERCPs performed (Figs. 1 and 2). These stents are composed of stainless steel or nitinol. ${ }^{50}$ The approach to placing fCSEMS begins with confirming the etiology, size and location of the stricture. If indeterminate, smaller than $5 \mathrm{~mm}$ or an intrahepatic stricture, one should avoid fCSEMS. ${ }^{10}$ Currently, 8 and $10 \mathrm{~mm}$ diameter fCSEMS are available in the USA and $8 \mathrm{~mm}$ stents should be used if duct size is $5-7 \mathrm{~mm}$, and $10 \mathrm{~mm}$ self-expanding metal stent (SEMS) should be used if $>8 \mathrm{~mm} .{ }^{10}$ One drawback of fCSEMs is the higher risk of migration. The endoscopist can take precautions to prevent internal migration. Leaving the stent long in the duodenum, not dilating prior to stent placement, and centering the stricture on fluoroscopy before deployment are all strategies in managing migration of the stent. If a fCSEMS is successfully placed, there is a high success of stricture resolution. In one study of 200 patients, $80-95 \%$ of patients had stricture resolution after SEMS. ${ }^{51}$

Associated with SEMS placement was a $16 \%$ migration rate and reports of tissue ingrowth and stent impaction. In another study by Cote et al. ${ }^{10}, 73$ patients who underwent fCSEMS after liver transplant showed no difference in stricture resolution rate or number of days to resolution. Deviere et al. ${ }^{13}$ looked at 42 patients after OLT who had received fCSEMS for AnS and found resolution of strictures in $68 \%$ of the patients. More proximal strictures are even more difficult to access with fCSEMS. Overall, fcSEMS have not been shown to be superior to plastic stents. ${ }^{30}$ Partially-covered SEMS provide a covered stent to manage the stricture, having theoretically lower migration rates, but removal can be problematic. ${ }^{50}$ Some groups have placed a stent without sphincterotomy in a stricture after LDLT. For this, a piece of nylon is attached to the distal end of the stent to allow for removal. ${ }^{52}$ Overall, further data is needed before any type of SEMS becomes the standard of care for management of AnS strictures.

In approximately $4-17 \%$ of cases, ERCP cannot be performed due to inability to traverse the stricture with a guidewire. ${ }^{21-23,53,54}$ Single- or double-balloon enteroscopy, or spiral-assisted enteroscopy can allow for endoscopic access of an AnS after a Roux-en-Y construction. Wang et al. ${ }^{55} \mathrm{dem}-$ onstrated cannulation in 12 of 13 patients and successful intervention rate at $90 \%$ when using single-balloon enteroscopy. In a study by Shah et al. ${ }^{56}$, a total of 129 patients that underwent enteroscopy then ERCP were studied. Ninety-two of the total patients $(71 \%)$ had a successful enteroscopy (Single- or double-balloon enteroscopy, or over-tube enteroscopy). Of the 92 patients in which the AnS was reached, $88 \%$ had a successful ERCP intervention. Roux-en-Y AnS can respond to dilation and drainage via PTC. Percutaneous stents can be left in for a year. Liver enzymes are monitored closely and, if normal, the percutaneous stent can be removed. ${ }^{5}$

Some new ERCP balloons have been developed to improve AnS therapy outcome. Two small studies showed a peripheral cutting balloon is more effective than standard pressure balloons, with a long-term patency rate of $78 \%$ compared to $55 \% .57,58$ Paclitaxel-eluting balloons have also been looked at for treating strictures. The hypothesis is that paclitaxel has antifibrotic properties which help to prevent fibroproliferation around the stricture. ${ }^{59}$ Another technique that had been reported is intraductal magnetic compression. ${ }^{1}$ In 


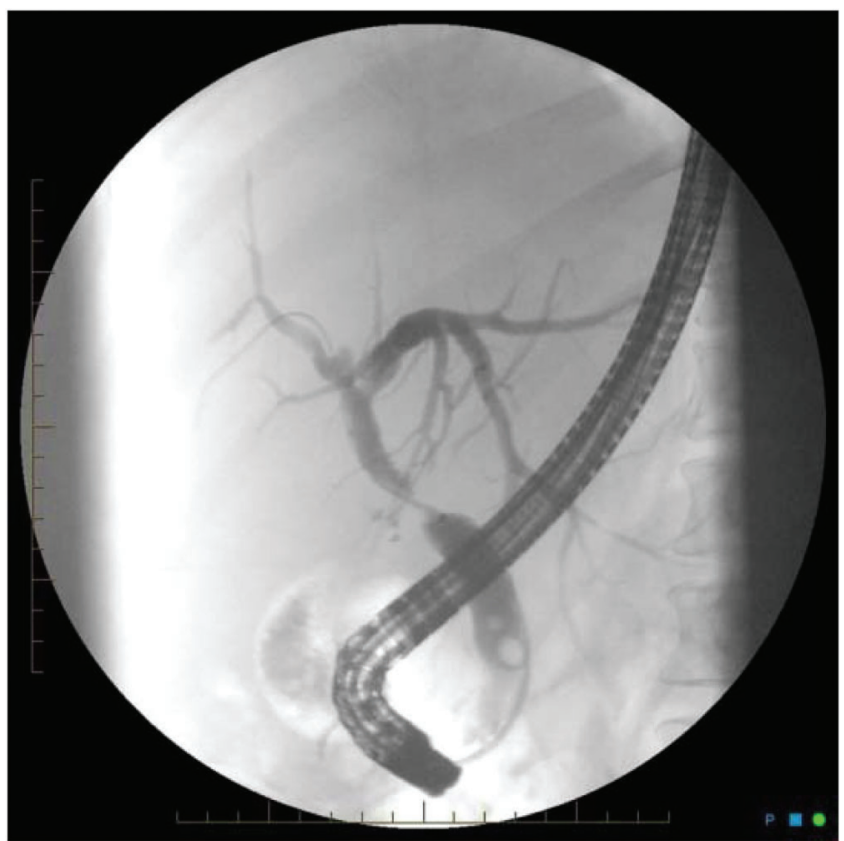

Fig. 1. Anastomotic stricture 10 months after orthotropic liver transplantation.

this technique, magnets are placed on both sides of the AnS by PTC above and ERCP below. Approximation of the magnets then occurs to resolve the stricture. In one study, it was successful in $84 \%(10 / 12)$ of the patients studied. In follow up, restenosis occurred in 1 patient. ${ }^{60}$ However, more studies are needed before cutting balloons, paclitaxel and magnet use become the standard of care. ${ }^{61,62}$

\section{Diagnosis of NAnS (hilar and intrahepatic)}

NAnS result from hepatic artery thrombosis or ischemic damage to the duct, which are the main risk factors for this biliary complication. NAnS are found more than $5 \mathrm{~mm}$ proximal to the anastomosis. ${ }^{30}$ NAnS can occur in both the extra- or intrahepatic ducts. The average time to NAnS development is usually 3-6 months. ${ }^{62,63}$ NAnS accounts for 10$25 \%$ of all strictures after OLT, with an overall incidence accounting for $1-15 \%$ of biliary complications. ${ }^{4,7,26,62-65}$ One theory suggests that the blood supply to the supraduodenal bile duct comes from vessels that are usually resected during OLT. In one study, $50 \%$ of patients with NAnS had no arterial collateral perfusion. ${ }^{65}$ Op den Dries et al. ${ }^{57}$ investigated 128 patients who had developed NAnS. Although those researchers found periductal vascular injury, the largest factor in NAnS may be the regenerative capability of the bile duct endothelium. ${ }^{38,58,61}$ Overall, the diagnostic algorithm usually follows the same pathway as AnS. ${ }^{64}$

\section{Management of NAnS}

Dominant NAnS usually require a smaller balloon to dilate than AnS. Balloon size of $4 \mathrm{~mm}$ is typically used. Additionally, placement of only a single plastic stent $(8.5-10 \mathrm{Fr})$ every 3 months is a common protocol. ${ }^{62}$ The efficacy of ERCP or PTC treatment is less than that of AnS, and these strictures

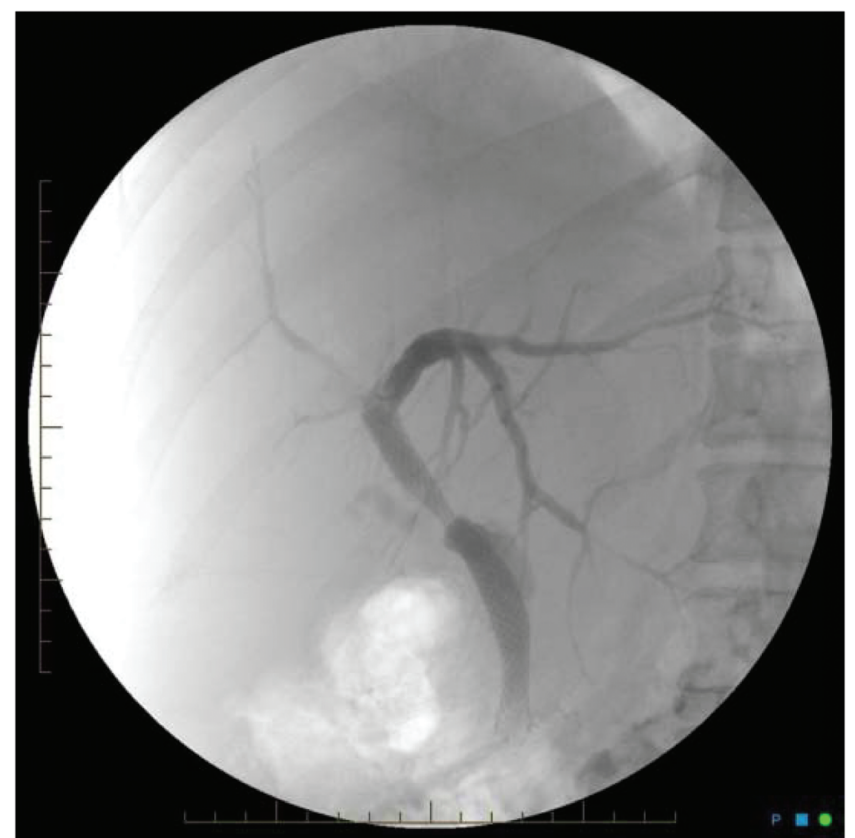

Fig. 2. Placement of $10 \mathrm{~mm} \times 6 \mathrm{~cm}$ partially covered self-expanding metal stent traversing the stricture.

require a longer duration of treatment. ${ }^{7}$ There is a higher rate of stent failure due to migration or occlusion. ${ }^{1}$

One study reported using $8.5-10 \mathrm{Fr}, 12-20 \mathrm{~cm}$ fenestrated stent with multiple side holes in the treatment of a proximal NAnS. ${ }^{66}$ The multiple side holes allow for circumferential drainage and represent a presumed advantage over CottonLeung or Amsterdam stents, which are rigid and have a single-end lumen. Johlin pancreatic wedge stents have been used in therapy of NAnS, due to their increased flexibility and side holes for drainage. ${ }^{50}$ NAnS strictures that occur in the intrahepatic region of the biliary tree are difficult to access endoscopically. Studies have shown that an inability to cannulate a stricture in the hilum was the major reason for impaired stricture resolution with NAnS. If cannulation is achieved, $80-90 \%$ of strictures could be treated. ${ }^{39,63,67}$ If the patient is not a candidate for repeat transplantation, stricture radiotherapy has been shown to reduce rates of infection, obstruction, and graft failure. ${ }^{5}$

\section{Digital cholangioscopy}

Single-operator per-oral cholangioscopy (Spyglass DS System; Boston Scientific, Natick, MA, USA) has been used for evaluation of refractory or complex NAnS and AnS strictures. This instrument allows direct visualization inside the bile duct and for further evaluation of the stricture in question. Once visualization is achieved, a guidewire can be passed through the tight stricture and this facilitates therapeutic interventions. ${ }^{68}$ Success rate with this method had been reported at $81 \%$ in one study. ${ }^{69}$ Furthermore, direct visualization of the bile duct allows for further characterization of stricture either from erythema, edema, or ulceration to help guide endoscopic therapy and predict resolution of stricture. ${ }^{50,70}$ Strictures formed from edema respond better to therapy compared to ulcerated strictures. ${ }^{70}$ Tissue sampling 


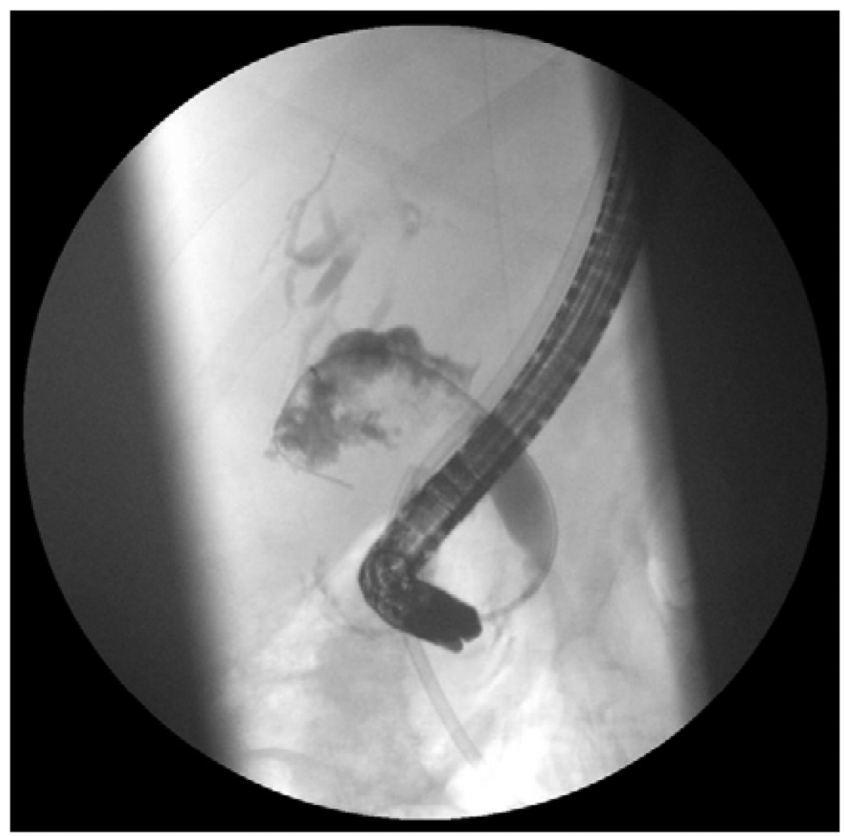

Fig. 3. Bile leak 4 months after orthotropic liver transplantation.

of strictures can be obtained if needed. A course of antibiotics should be given prophylactically, whenever direct cholangioscopy is used, due to the immunosuppression in the post-OLT patient causing an increased risk of bacterial translocation, as water irrigation is used for insufflation to visualize the duct.

Fifty percent of patients with NAnS have long-term response to PTC or ERCP therapy. ${ }^{3,5-7,28,62,63,71}$ If biliary tract therapy fails, Roux-en-Y choledochojejunostomy is usually performed with duct-to-duct anastomosis. If Rouxen-Y was already done, trimming the bile duct to the graft where there is evidence of good vascularization has been shown to prevent recurrence of the stricture. ${ }^{5}$ Retransplantation is also an option.

\section{Bile leaks}

Bile leaks occur in the range of $2-25 \%$ post-transplant. $^{2-6,25,26,72,73}$ The majority of bile leaks will be seen 1 day to 6 months after transplant. ${ }^{1,74}$ ERCP is a very effective for both diagnosis and treatment of a bile leak, usually requiring on average two ERCP sessions (Figs. 3, 4, and 5). ${ }^{27} \mathrm{~A}$ bile leak is a risk factor for strictures and vice versa. A bile leak can occur from the anastomosis, PTC tube tract, the cut surface of the liver (Luschka's duct), or from the cystic duct remnant. ${ }^{17}$ The anastomosis site is the most common.

In a review of 55 articles on bile leaks, $7.8 \%(668 / 8585)$ occurred amongst DDLT patients and 9.5\% (268/2812) occurred with LDLT. ${ }^{74}$ The diagnosis of bile leaks should be suspected in patients with fever and signs of peritonitis after liver transplantation or after T-tube removal. Some patients may not be symptomatic in the setting of immunosuppression. If there is elevation of bilirubin, change in cyclosporine levels or bile in ascitic fluid, one should raise the question of a bile leak. ${ }^{75}$

US or CT/MRI can be pursued if there is a concern for a bile leak causing an extrahepatic collection. If there is a frank

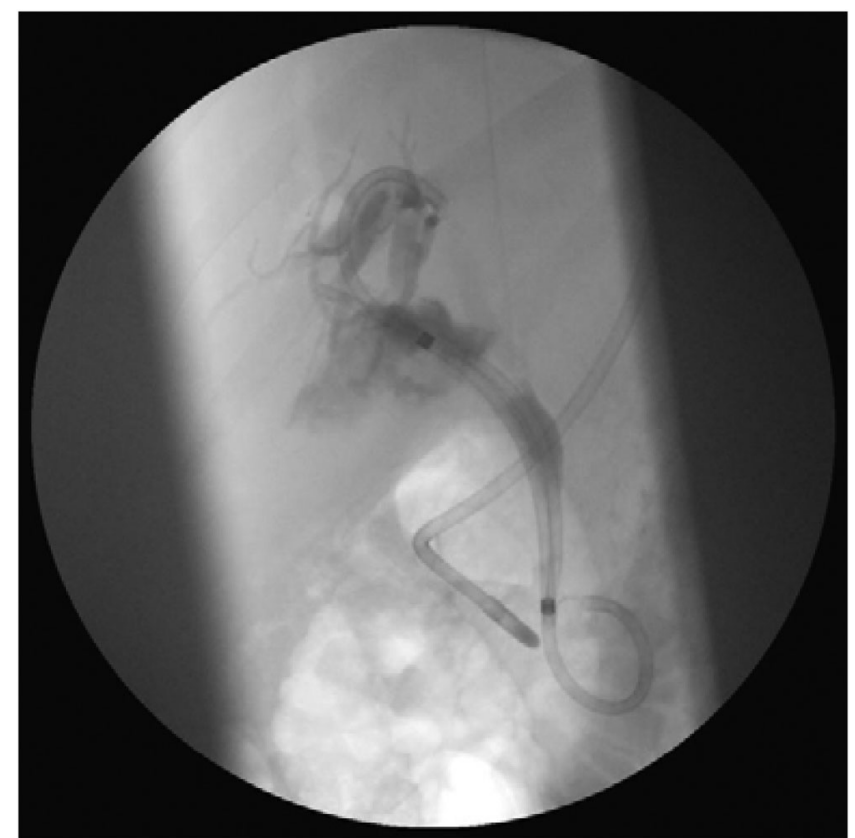

Fig. 4. Successful placement of two $10 \mathrm{Fr} \times 9 \mathrm{~cm}$ plastic stents traversing bile leak.

collection seen, direct percutaneous drainage by interventional radiology should be considered. If no overt signs of a bile leak are seen on those imaging modalities, a hepatobiliary iminodiacetic acid (known as HIDA) scan has an $80 \%$ specificity and a $50 \%$ sensitivity for detecting a leak. ${ }^{76,77}$ Bile leaks are usually divided into two groups based on time of presentation (early or late).

\section{Early bile leaks ( $<4$ weeks)}

Early anastomotic leaks usually occur because of technical problems related to surgery. Causes of bile leaks include active bleeding at the bile duct end, excessive dissection of periductal tissue at time of procurement, tension on ductal anastomosis, incorrect suture of the cystic duct stump, or use of electrocautery to control bleeding. ${ }^{5}$

\section{Late bile leak ( $>4$ weeks)}

Late bile leaks are usually related to premature T-tube removals, at which time a fistula tract may have developed. Pain with removal of the tube may be suggestive of a bile leak, which can evolve into biliary peritonitis. In one study, $31 \%$ of patients with a T-tube reported a bile leak, with $7 \%$ being late. $^{5}$

\section{Management of bile leaks}

If a T-tube is in place, bile flow will be diverted and will often times result in closure of the leak in $1 / 3$ to $1 / 2$ of leak closure within the first 24 hours. ${ }^{1,78}$ For the remaining patients, the majority will require ERCP with sphincterotomy and stenting or biliary diversion, with either through nasobiliary drainage. Treatment by ERCP with plastic stent has resolved early bile leaks in $90-95 \%$ of cases. ${ }^{5,6,79,80}$ Immediately 
Moy B.T. et al: Biliary complications after OLT

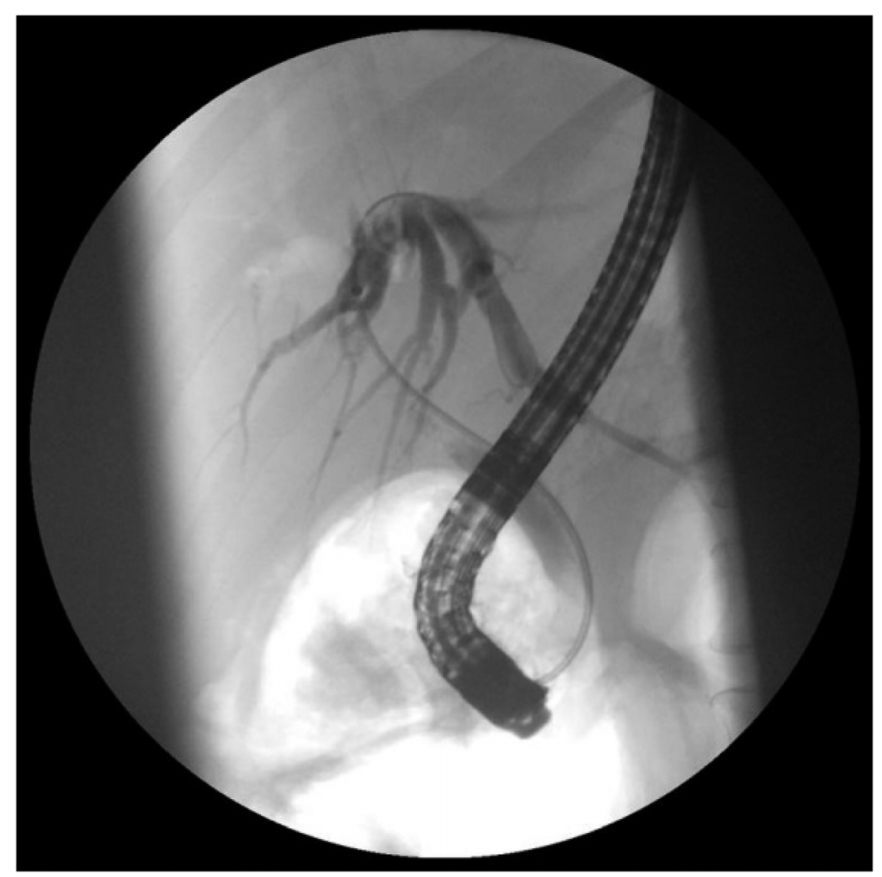

Fig. 5. Resolution of bile leak 2 months after placement.

post-operative, $25-33 \%$ of bile leaks will resolve spontaneously in 24 hours. ${ }^{78}$ Usually, a sphincterotomy is performed, then a transpapillary stent is placed for 2-3 months to divert bile away from the leak. ${ }^{30}$ This helps decrease the transpapillary pressure gradient that can exacerbate bile leaks. ${ }^{81}$ Longer duration of stent placement is recommended in OLT cases compared to the usual 4-6 weeks when a stent is placed post-cholecystectomy because of delayed healing in the setting of immunosuppression. ${ }^{30}$ Bile duct clearance of stones and sludge should be performed after the stent is removed, as there is a high incidence of concurrent sludge or stones with bile leaks. ${ }^{82}$ fcSEMS have been looked at in treating bile leaks. In a small study with 17 patients, $47 \%$ (or 8) patients developed CBD strictures after removal of the stent. ${ }^{83}$ fCSEMS after OLT can be considered in refractory leaks or larger bile leaks. ${ }^{84}$ If a T-tube is in place after stenting, it should be removed in 1-2 days after successful stent placement. $^{5}$

Roux-en-Y choledochojejunostomy bile leaks are rarer. The intestinal loop of the anastomosis may lead to the formation of intra-abdominal abscess and sepsis. ${ }^{5}$ Leaks after Roux-en-Y can be diagnosed by HIDA scan. ERCP is often difficult, given the anatomy. If unable to obtain biliary access endoscopically, a percutaneous internal-external drain can be used to drain bile leaks but surgery will be needed if these above measures fail. If successful, PTC with both an internal and external drain can be up-sized and used for 3-6 months until drainage has stopped. ${ }^{5}$ Another novel approach reported is a technique where a gastrostomy is formed using EUS and then ERCP is performed through gastrostomy port. Successful biliary intervention was achieved in $9 / 10$ patients compared to the $58 \%$ success with deep enteroscopy. ${ }^{85,86}$ Nasobiliary tubes have also been effective in treating bile leaks. After the initial ERCP, a biliary drain is placed proximal to the leak. ${ }^{68}$ These allow frequent cholan- giograms in follow up (every 3-5 days) without repeat ERCP. ${ }^{87}$ In one study, the average time to fistula closing was 6.3 days. ${ }^{80} \mathrm{~A}$ drawback to this approach, however, may be diversion of bile from the intestine causing decreased drug reabsorption.

\section{Bile duct stones}

Filling defects can be seen after liver transplantation, due to stones, sludge, migrated stents, casts, or clots. ${ }^{5}$ Incidence of filling defects occurs between $2.5-12 \%$ post-OLT. $3,6,25,64,88-90$ Bile sludge can occur due to cyclosporine's increased lithogencitiy. Strictures, ischemia, and infections predispose the formation of common bile duct (CBD) filling defects. $5,27,72,91$ Additionally, mucosal damage, ischemia, infection, foreign bodies, cholesterol supersaturation, and bile pool depletion may play a role in formation of stones. ${ }^{1,60,92}$ The median time for stone formation is 19 months and it is more common after OLT.

\section{Management of bile duct stones}

ERCP is the initial therapeutic test to remove bile duct stones. Overall, ERCP is successful in $90-100 \%$ of patients for clearance of stones. ${ }^{17,24}$ There was a $17 \%$ recurrence rate of an obstructing stone within 6 months of removal of the initial stone, in one study. ${ }^{3}$ In another study, two sessions were required in $24 \%$ of patients, and three or more sessions were required in $17 \%$ of patients. ${ }^{93,94}$ Ursodiol can be considered as a preventive against formation of stones, but more research needs to be done to define its long-term efficacy. ${ }^{5}$ 


\section{Biliary cast syndrome}

Biliary cast syndrome marks the presence of multiple, hard, and pigmented brown casts causing obstruction. Reported incidence is $2.5-18 \% .{ }^{18,95}$ Biliary cast syndrome was present in $2.5 \%$ of patients in one retrospective OLT study looking at 355 transplantations. ${ }^{90,96}$ The etiology of biliary cast syndrome is thought to be from acute cellular rejection, ischemia, infection, and biliary obstruction from stasis. ${ }^{1}$ Damage of the biliary tree mucosa can cause formation of desquamated epithelial cells (casts) combined with lithogenic bile. ${ }^{97}$ Increased risks for this syndrome include hepatic artery stenosis and strictures. ${ }^{96}$ In one study, ERCP was successful in treating $60 \%$ of patients with biliary cast syndrome. ${ }^{98}$ If casts develop in a patient with a Roux-en-Y, percutaneous access should be attempted to remove casts.

\section{Biloma}

Most bilomas will occur outside the liver in the perihepatic space. The incidence is not well defined, but one study by Said et $a l .{ }^{99}$ reported an incidence of $11.5 \%$. Small bilomas are oftentimes self-limiting. ${ }^{93}$ Larger bilomas should be drained percutaneously and antibiotics should be given. If it occurs within the liver amongst the biliary tree, transpapillary stent and endoscopy can be used for management; however, ERCP is often diagnostic and not therapeutic. If no communication is present, percutaneous drainage and antibiotics should be used. Taking a transgastric approach via endoscopic US is another option to drain bilomas. ${ }^{50}$ Surgery is indicated when the biloma cannot be controlled with the above management.

\section{Hemobilia}

Hemobilia can occur after PTC or biopsy. ${ }^{100}$ It is an uncommon presentation, reported in one study to have a frequency of $1.2 \%$ in 2701 patients. $^{76}$ In another study of 33 patients with hemobilia, ERCP placement of nasobiliary drainage improved symptoms in $87.9 \% .{ }^{76}$ For significant hemobilia, careful angiographic therapy should be used to achieve hemostasis. If there are evidence of clot formation, ERCP can be used for clearance of the bile duct.

\section{Mucocele}

A mucocele is a collection of mucous from cells lining the cystic duct remnant, causing compression of the bile duct. ${ }^{77,101,102}$ It is a rare biliary complication in the post-transplant patient. On US, mucocele will appear as a fluid collection in the porta hepatis. Yet, diagnosis is usually not made for weeks to years. ${ }^{5}$ It should be distinguished from other radiographic findings that appear similar, including abscess, biloma, hemobilia, tumor, or aneurysm. Diagnosis can be confirmed with MRCP. ${ }^{5}$ Surgery or drainage from the cystic duct bed is usually the management course. Endoscopic therapy has not been shown to be effective and is not recommended. ${ }^{102}$

\section{Redundant CBD}

A rare biliary complication that has been described in the literature is a redundant CBD after OLT. The donor duct can be longer than the recipient's CBD, causing a sigmoid-shaped loop that can cause cholestasis, leading to biliary complications. ${ }^{103}$ Incidence has been reported to be $1.6 \%$ of all OLT. In
$80 \%$ of patients, the loop resolved after placing a long plastic stent. If that fails, Roux-en-Y hepaticojejunostomy is the next definitive step. ${ }^{103}$

\section{Bactobilia}

The clinical significance of bactobilia is not known, but may be a risk factor in development of biliary complications. In one study, bile samples were collected from 66 patients post-OLT, with $73 \%$ of the patients being positive for microorganisms. Forty-eight percent had Gram-positive bacteria, 39\% had Gram-negative, $3 \%$ had anaerobic bacteria and $9 \%$ had fungi. ${ }^{104}$ Nineteen patients out of the 66 with bactobilia experienced clinical signs of cholangitis. ${ }^{104}$ All 19 of these patients were papillotomized and all but one had insertion of a plastic stent for therapy. ${ }^{104}$ More studies need to be performed looking at the clinical impact of bactobilia.

\section{Biliary complications following LDLT}

Due to lack of availability of cadaveric livers, LDLT has gained increasing popularity with adult patients in recent years. ${ }^{30}$ Biliary complications are frequent after undergoing LDLT and the anatomy is often difficult, as Roux-en-Y hepaticojejunostomy and Roux-en-Y gastric bypass are encountered after transplant.50 Ductal devascularization of the right hepatic duct stump at time of harvesting often causes more prolonged ischemia time, increasing biliary complications. ${ }^{81}$ During LDLT, the recipient's common hepatic duct needs to be divided in the hilum to avoid tension at the anastomosis. This oftentimes alters the blood supply to the hepatic duct stump, which comes from the gastrodudoenal artery below. ${ }^{105-107}$

Overall incidence of complications is $6-40 \%$, with leaks occurring in $22 \%$ of patients, and $40 \%$ developing strictures. ${ }^{108}$ There is 2-3-times increased risk of biliary complications with LDLT. Risk factors are similar to those of DDLT and include age and gender, $\mathrm{ABO}$ compatibility, cytomegalovirus infection, biliary leakage, multiple ducts for anastomosis, and type of reconstruction performed. ${ }^{109-111}$ ERCP is more difficult in LDLT recipients. The ducts are smaller with LDLT, require the use of smaller balloons, and the placement of small $7 \mathrm{Fr}$ stents in the strictures, requiring multiple ERCPs with stent exchange. ${ }^{39}$

Stricture resolution is lower in LDLT than in DDLT, with a range of $31 \%$ to $85 \%$. The most common reason for failure is inability to access the small bile duct branches. ${ }^{7,25,53,112}$ Median time to onset of a biliary stricture is 5.9 months in one study looking at LDLT patients. ${ }^{64}$ Hsieh et al. ${ }^{51}$ looked at 110 patients retrospectively who had undergone LDLT and duct-to-duct anastomosis. This study was looking at the outcomes of endoscopic approach to AnS after LDLT with dilation and multiple stent placement. Thirty-two out of thirtyeight $(84 \%)$ had successful resolution of strictures after endoscopic treatment. No patients needed retransplantation or surgical intervention. ${ }^{51}$ Tsujino et al. looked at 174 patients that underwent LDLT with duct-to-duct biliary reconstructions. Complications developed in $53(30 \%)$ of the patients. Seventeen patients had endoscopic intervention for a biliary stricture. Twelve patients (71\%) had successful treatment of the stricture. Bile leaks occur at higher frequency in LDLT due to the cut edge of the transplanted liver. Because of higher risk of failure with LDLT, PTC or surgery are backup modalities for treatment of refractory biliary complications.

Donors may also experience complications in LDLT. In 200 donors looked at, 26 had bile leaks (13\%) and 3 had strictures 


\title{
Post-orthotropic Liver Transplantation Biliary Complication
}

\begin{abstract}
Ultrasound/computed tomography can be initial test in workup for abnormal LFTs. If biliary complication suspect, magnetic resonance cholangiopancreatography is the initial preferred diagnostic modality. Hepatobiliary iminodiacetic acid scan can be pursued if there is low suspicion for a bile leak. Confirm etiology and location of the stricture $+/$ - leak. ERCP is then the preferred therapeutic modality. Sphincterotomy is not necessary for inserting a single plastic stent or a SEMS, but may facilitate more complex procedures. If failed endoscopic therapy, next consider PTC. Revision surgery is an option if there is a continued complication despite prior interventions.
\end{abstract}

\begin{tabular}{|c|c|c|c|}
\hline Biliary Stricture with fCSEMS & $\begin{array}{c}\text { Anastomotic/Non- } \\
\text { anastomotic Stricture }\end{array}$ & Biliary Leak & $\begin{array}{c}\text { Refractory } \\
\text { Choledocholithaisis }\end{array}$ \\
\hline $\begin{array}{l}\text { 1. Consider fcSEMS if failed } \\
\text { therapy with plastic stents and } \\
\text { dilation. } \\
\text { 2. Avoid fcSEMS for strictures of } \\
\text { indeterminate etiology. } \\
\text { 3. Avoid placement for } \\
\text { intrahepatic strictures. } \\
\text { 4. Evaluate diameter of stricture. } \\
\text { 5. If stricture diameter }<5 \mathrm{~mm} \\
\text { avoid SEMS, } 5-7 \mathrm{~mm} \text { begin } \\
\text { with } 8 \text { mm SEMS, and }>8 \mathrm{~mm} \\
\text { start with } 10 \text { mm SEMS to } \\
\text { prevent oversizing the bile duct. } \\
\text { 6. Place one fCSEMS. } \\
\text { 7. Clinical and laboratory studies } \\
\text { every } 3 \text { months. } \\
\text { 8. Repeat ERCP q6 months for } \\
\text { assessment of stricture, repeat } \\
\text { stenting, or stent removal. }\end{array}$ & $\begin{array}{l}\text { 1. Balloon dilation. } \\
\text { 2. Placement of } 10 \text { Fr stents } \\
\text { to achieve maximum } \\
\text { radial tension. The more } \\
\text { stents used, the higher the } \\
\text { resolution rate. } \\
\text { 3. Repeat ERCP q } 3 \text { months } \\
\text { with stacking to achieve } \\
\text { continued radial tension. } \\
\text { 4. Repeat step } 3 \text { until } \\
\text { resolution of stricture on } \\
\text { fluoroscopy. } \\
\text { 5. If stricture has not } \\
\text { resolved after } 12 \text { months, } \\
\text { consider switching to } \\
\text { fCSEMS. }\end{array}$ & $\begin{array}{l}\text { 1. ERCP should be used to } \\
\text { locate leak. } \\
\text { 2. If no lesion can be } \\
\text { identified a plastic biliary } \\
\text { stent placement without } \\
\text { sphincetrotomy is } \\
\text { recommended. } \\
\text { 3. Remove stent within } 8 \text { to } \\
12 \text { weeks. At time of } \\
\text { stent removal, } \\
\text { cholangiography and } \\
\text { clearance of the duct } \\
\text { should be performed. } \\
\text { 4. Consider early PTC } \\
\text { internal/external drainage } \\
\text { if the leak is localized } \\
\text { around disrupted suture } \\
\text { line. }\end{array}$ & $\begin{array}{l}\text { 1. If stones are } \\
\text { irretrievable after } \\
\text { ERCP with } \\
\text { lithotripsy, balloon } \\
\text { dilatation, or plastic } \\
\text { stents are effective } \\
\text { to establish biliary } \\
\text { drainage. } \\
\text { 2. Ursodeoxycholic } \\
\text { acid can be } \\
\text { considered for } \\
\text { stone dissolution. }\end{array}$ \\
\hline
\end{tabular}

Fig. 6. Decision tree for managing biliary complications after orthotropic liver transplantation. ${ }^{1,82}$ Abbreviations: $E R C P$, endoscopic retrograde cholangiopancreatography; fCSEMS, fully covered self-expanding metal stent; PTC, percutaneous transhepatic cholangiography; SEMS, self-expanding metal stent.

$(1.5 \%)$ in the monitoring period of 28.7 months. ${ }^{113}$ In a study of 1508 donors in Asia, more complications were associated with right-lobe than left-lobe or left lateral transplantation. ${ }^{114}$

\section{Conclusions}

Biliary tract complications are often seen complicating OLT, with an overall incidence of $10-25 \%$. The possibility of a biliary complication should be raised in the presence of a fever, right upper quadrant abdominal pain, or increased white blood cell count and LFTs. Initial evaluation should begin with Doppler US and consideration of advanced imaging with MRCP. MRCP is a good test to establish the initial diagnosis and assess the biliary system if there is a low likelihood of a biliary complication. ${ }^{115}$ If significant biliary pathology is suspected, ERCP and or PTC should be utilized primarily for therapy.

Strictures are best treated with balloon dilation with routine stent exchanges. Most patients will require 3-5 ERCPs, with multiple plastic or metal stents placed and exchanged for at least a year before stricture resolution (Fig. 6). ${ }^{115}$ If there is a bile leak, ERCP stent exchanges should occur at 2-3 month intervals, due to concern over immunosuppression. ${ }^{115}$ Although rarer, common duct stones, biliary cast syndrome, mucocele, bilomas, and hemobilia can be managed with ERCP or PTC. ERCP and/or percutaneous intervention can avoid repeat surgery. Early identification and aggressive treatment of these complications have shown to improve morbidity, mortality, and graft survival after liver transplantation. 
Moy B.T. et al: Biliary complications after OLT

\section{Acknowledgment}

Figures 1-5 are courtesy of Colin T. Swales, MD.

\section{Conflict of interest}

The authors have no conflict of interests related to this publication.

\section{Author contributions}

Wrote the manuscript and reviewed the literature (BTM), revised and edited the manuscript for important intellectual content and format (JWB).

\section{References}

[1] Lee HW, Shah NH, Lee SK. An update on endoscopic management of postliver transplant biliary complications. Clin Endosc 2017;50:451-463. doi: 10.5946/ce.2016.139.

[2] Stratta RJ, Wood RP, Langnas AN, Hollins RR, Bruder KJ, Donovan JP, et al. Diagnosis and treatment of biliary tract complications after orthotopic liver transplantation. Surgery 1989;106:675-683; discussion 683-684.

[3] Rerknimitr R, Sherman S, Fogel EL, Kalayci C, Lumeng L, Chalasani N, et al. Biliary tract complications after orthotopic liver transplantation with choledochocholedochostomy anastomosis: endoscopic findings and results of therapy. Gastrointest Endosc 2002;55:224-231. doi: 10.1067/mge.2002. 120813.

[4] Greif F, Bronsther OL, Van Thiel DH, Casavilla A, Iwatsuki S, Tzakis A, et al. The incidence, timing, and management of biliary tract complications after orthotopic liver transplantation. Ann Surg 1994;219:40-45. doi: 10. 1097/00000658-199401000-00007.

[5] Thuluvath PJ, Pfau PR, Kimmey MB, Ginsberg GG. Biliary complications after liver transplantation: the role of endoscopy. Endoscopy 2005;37:857-863. doi: $10.1055 / \mathrm{s}-2005-870192$.

[6] Pfau PR, Pleskow DK, Banerjee S, Barth BA, Bhat YM, Desilets DJ, et al. Pancreatic and biliary stents. Gastrointest Endosc 2013;77:319-327. doi: 10.1016/j.gie.2012.09.026.

[7] Rizk RS, McVicar JP, Emond MJ, Rohrmann CA Jr, Kowdley KV, Perkins J, et al. Endoscopic management of biliary strictures in liver transplant recipients: effect on patient and graft survival. Gastrointest Endosc 1998;47: 128-135. doi: 10.1016/s0016-5107(98)70344-x.

[8] Balderramo D, Bordas JM, Sendino O, Abraldes JG, Navasa M, Llach J, et al. Complications after ERCP in liver transplant recipients. Gastrointest Endosc 2011;74:285-294. doi: 10.1016/j.gie.2011.04.025.

[9] Mahnke D, Chen YK, Antillon MR, Brown WR, Mattison R, Shah RJ. A prospective study of complications of endoscopic retrograde cholangiopancreatography and endoscopic ultrasound in an ambulatory endoscopy center. Clin Gastroenterol Hepatol 2006;4:924-930. doi: 10.1016/j.cgh.2006.04.006.

[10] Coté GA, Slivka A, Tarnasky P, Mullady DK, Elmunzer B], Elta G, et al. Effect of covered metallic stents compared with plastic stents on benign biliary stricture resolution: A randomized clinical trial. JAMA 2016;315:12501257. doi: 10.1001/jama.2016.2619.

[11] Gómez R, Moreno E, Castellón C, González-Pinto I, Loinaz C, García I. Choledochocholedochostomy conversion to hepaticojejunostomy due to biliary obstruction in liver transplantation. World J Surg 2001;25:1308-1312. doi: 10.1007/s00268-001-0115-3.

[12] Sanchez-Urdazpal L, Gores GJ, Ward EM, Maus TP, Buckel EG, Steers JL, et al. Diagnostic features and clinical outcome of ischemic-type biliary complications after liver transplantation. Hepatology 1993;17:605-609. doi: 10.1002/hep.1840170413.

[13] Devière J, Nageshwar Reddy D, Püspök A, Ponchon T, Bruno MJ, Bourke MJ, et al. Successful management of benign biliary strictures with fully covered self-expanding metal stents. Gastroenterology 2014;147:385-395; quiz e15. doi: 10.1053/j.gastro.2014.04.043.

[14] Elmunzer BJ, Debenedet AT, Volk ML, Sonnenday CJ, Waljee AK, Fontana RJ, et al. Clinical yield of diagnostic endoscopic retrograde cholangiopancreatography in orthotopic liver transplant recipients with suspected biliary complications. Liver Transpl 2012;18:1479-1484. doi: 10.1002/It.23535.

[15] Fung J], Eghtesad B, Patel-Tom K. Using livers from donation after cardiac death donors-a proposal to protect the true Achilles heel. Liver Transpl 2007;13:1633-1666. doi: 10.1002/lt.21388.

[16] Graziadei IW. Recurrence of primary sclerosing cholangitis after liver transplantation. Liver Transpl 2002;8:575-581. doi: 10.1053/jits.2002.33952.
[17] Maheshwari A, Maley W, Li Z, Thuluvath PJ. Biliary complications and outcomes of liver transplantation from donors after cardiac death. Liver Transpl 2007;13:1645-1653. doi: 10.1002/lt.21212.

[18] Sharma S, Gurakar A, Jabbour N. Biliary strictures following liver transplantation: past, present and preventive strategies. Liver Transpl 2008;14:759769. doi: 10.1002/It.21509.

[19] Amador A, Charco R, Marti J, Alvarez G, Ferrer J, Mans E, et al. Cost/efficacy clinical trial about the use of T-tube in cadaveric donor liver transplant: preliminary results. Transplant Proc 2005;37:1129-1130. doi: 10.1016/j. transproceed.2005.01.015.

[20] Sun N, Zhang J, Li X, Zhang C, Zhou X, Zhang C. Biliary tract reconstruction with or without T-tube in orthotopic liver transplantation: a systematic review and meta-analysis. Expert Rev Gastroenterol Hepatol 2015;9: 529-538. doi: 10.1586/17474124.2015.1002084.

[21] Verdonk RC, Buis CI, Porte RJ, van der Jagt EJ, Limburg AJ, van den Berg AP, et al. Anastomotic biliary strictures after liver transplantation: causes and consequences. Liver Transpl 2006;12:726-735. doi: 10.1002/It.20714.

[22] Barriga J, Thompson R, Shokouh-Amiri H, Davila R, Ismail MK, Waters B, et al. Biliary strictures after liver transplantation. Predictive factors for response to endoscopic management and long-term outcome. Am J Med Sci 2008;335:439-443. doi: 10.1097/MAJ.0b013e318157d3b5.

[23] Morelli J, Mulcahy HE, Willner IR, Cunningham JT, Draganov P. Long-term outcomes for patients with post-liver transplant anastomotic biliary strictures treated by endoscopic stent placement. Gastrointest Endosc 2003; 58:374-379. doi: 10.1067/s0016-5107(03)00011-7.

[24] Potthoff A, Hahn A, Kubicka S, Schneider A, Wedemeyer J, Klempnauer J, et al. Diagnostic value of ultrasound in detection of biliary tract complications after liver transplantation. Hepat Mon 2013;13:e6003. doi: 10. 5812/hepatmon.6003.

[25] Thuluvath PJ, Atassi T, Lee J. An endoscopic approach to biliary complications following orthotopic liver transplantation. Liver Int 2003;23:156-162. doi: 10.1034/j.1600-0676.2003.00823.x

[26] Thethy S, Thomson BNJ, Pleass H, Wigmore SJ, Madhavan K, Akyol M, et al. Management of biliary tract complications after orthotopic liver transplantation. Clin Transplant 2004;18:647-653. doi: 10.1111/j.1399-0012.2004. 00254.x.

[27] Verdonk RC, Buis CI, Porte RJ, Haagsma EB. Biliary complications after liver transplantation: a review. Scand J Gastroenterol Suppl 2006;243:89-101. doi: 10.1080/00365520600664375.

[28] Pascher A, Neuhaus P. Biliary complications after deceased-donor orthotopic liver transplantation. J Hepatobiliary Pancreat Surg 2006;13:487496. doi: 10.1007/s00534-005-1083-z.

[29] Vallera RA, Cotton PB, Clavien PA. Biliary reconstruction for liver transplantation and management of biliary complications: overview and survey of current practices in the United States. Liver Transpl Surg 1995;1:143152. doi: $10.1002 /$ It. 500010302 .

[30] Macías-Gómez C, Dumonceau JM. Endoscopic management of biliary complications after liver transplantation: An evidence-based review. World J Gastrointest Endosc 2015;7:606-616. doi: 10.4253/wjge.v7.i6.606.

[31] Sanchez-Urdazpal L, Batts KP, Gores G], Moore SB, Sterioff S, Wiesner RH, et al. Increased bile duct complications in liver transplantation across the ABO barrier. Ann Surg 1993;218:152-158. doi: 10.1097/00000658199308000-00006.

[32] Sanchez-Urdazpal L, Gores G], Ward EM, Maus TP, Wahlstrom HE, Moore $\mathrm{SB}$, et al. Ischemic-type biliary complications after orthotopic liver transplantation. Hepatology 1992;16:49-53. doi: 10.1002/hep.1840160110.

[33] Busquets J, Figueras ], Serrano T, Torras J, Ramos E, Rafecas A, et al. Postreperfusion biopsies are useful in predicting complications after liver transplantation. Liver Transpl 2001;7:432-435. doi: 10.1053/jlts.2001.23868.

[34] Welling TH, Heidt DG, Englesbe MJ, Magee JC, Sung RS, Campbell DA, et al. Biliary complications following liver transplantation in the model for endstage liver disease era: effect of donor, recipient, and technical factors. Liver Transpl 2008;14:73-80. doi: 10.1002/It.21354.

[35] Dacha S, Barad A, Martin J, Levitsky J. Association of hepatic artery stenosis and biliary strictures in liver transplant recipients. Liver Transpl 2011;17: 849-854. doi: 10.1002/It.22298.

[36] Jay CL, Lyuksemburg V, Ladner DP, Wang E, Caicedo JC, Holl JL, et al. Ischemic cholangiopathy after controlled donation after cardiac death liver transplantation: a meta-analysis. Ann Surg 2011;253:259-264. doi: 10.1097/SLA.0b013e318204e658.

[37] Sundaram V, Jones DT, Shah NH, de Vera ME, Fontes P, Marsh JW, et al. Posttransplant biliary complications in the pre- and post-model for endstage liver disease era. Liver Transpl 2011;17:428-435. doi: 10.1002/It. 22251.

[38] Brunner SM, Junger H, Ruemmele P, Schnitzbauer AA, Doenecke A, Kirchner GI, et al. Bile duct damage after cold storage of deceased donor livers predicts biliary complications after liver transplantation. J Hepatol 2013;58: 1133-1139. doi: 10.1016/j.jhep.2012.12.022.

[39] Roos FJM, Poley JW, Polak WG, Metselaar HJ. Biliary complications after liver transplantation; recent developments in etiology, diagnosis and endoscopic 
treatment. Best Pract Res Clin Gastroenterol 2017;31:227-235. doi: 10. 1016/j.bpg.2017.04.002.

[40] Scatton O, Meunier B, Cherqui D, Boillot O, Sauvanet A, Boudjema K, et al. Randomized trial of choledochocholedochostomy with or without a T tube in orthotopic liver transplantation. Ann Surg 2001;233:432-437. doi: 10. 1097/00000658-200103000-00019.

[41] Vougas V, Rela M, Gane E, Muiesan P, Melendez HV, Williams R, et al. A prospective randomised trial of bile duct reconstruction at liver transplantation: $T$ tube or no $T$ tube? Transpl Int 1996;9:392-395. doi: 10. $1007 / \mathrm{bf00335701.}$

[42] Koivusalo A, Isoniemi H, Salmela K, Edgren J, von Numers H, Höckerstedt K. Biliary complications in one hundred adult liver transplantations. Scand J Gastroenterol 1996;31:506-511. doi: 10.3109/00365529609006773.

[43] Sotiropoulos GC, Sgourakis G, Radtke A, Molmenti EP, Goumas K, Mylona S, et al. Orthotopic liver transplantation: T-tube or not T-tube? Systematic review and meta-analysis of results. Transplantation 2009;87:16721680. doi: $10.1097 /$ TP.0b013e3181a5cf3f.

[44] Riediger C, Müller MW, Michalski CW, Hüser N, Schuster T, Kleeff J, et al. T-Tube or no T-tube in the reconstruction of the biliary tract during orthotopic liver transplantation: systematic review and meta-analysis. Liver Transpl 2010;16:705-717. doi: 10.1002/lt.22070.

[45] Zoepf T, Maldonado-Lopez EJ, Hilgard P, Malago M, Broelsch CE, Treichel U, et al. Balloon dilatation vs. balloon dilatation plus bile duct endoprostheses for treatment of anastomotic biliary strictures after liver transplantation. Liver Transpl 2006;12:88-94. doi: 10.1002/It.20548.

[46] Alazmi WM, Fogel EL, Watkins JL, McHenry L, Tector JA, Fridell J, et al. Recurrence rate of anastomotic biliary strictures in patients who have had previous successful endoscopic therapy for anastomotic narrowing after orthotopic liver transplantation. Endoscopy 2006;38:571-574. doi: 10. 1055/s-2006-925027.

[47] Kao D, Zepeda-Gomez S, Tandon P, Bain VG. Managing the post-liver transplantation anastomotic biliary stricture: multiple plastic versus metal stents: a systematic review. Gastrointest Endosc 2013;77:679-691. doi: 10.1016/j.gie.2013.01.015.

[48] Tabibian JH, Asham EH, Han S, Saab S, Tong MJ, Goldstein L, et al. Endoscopic treatment of postorthotopic liver transplantation anastomotic biliary strictures with maximal stent therapy (with video). Gastrointest Endosc 2010;71:505-512. doi: 10.1016/j.gie.2009.10.023.

[49] Costamagna G, Pandolfi M, Mutignani M, Spada C, Perri V. Long-term results of endoscopic management of postoperative bile duct strictures with increasing numbers of stents. Gastrointest Endosc 2001;54:162-168. doi: 10.1016/s0016-5107(01)70100-9.

[50] Girotra M, Soota K, Klair JS, Dang SM, Aduli F. Endoscopic management of post-liver transplant biliary complications. World J Gastrointest Endosc 2015;7:446-459. doi: 10.4253/wjge.v7.i5.446.

[51] Hsieh TH, Mekeel KL, Crowell MD, Nguyen CC, Das A, Aqel BA, et al. Endoscopic treatment of anastomotic biliary strictures after living donor liver transplantation: outcomes after maximal stent therapy. Gastrointest Endosc 2013;77:47-54. doi: 10.1016/j.gie.2012.08.034.

[52] Kurita A, Kodama Y, Minami R, Sakuma Y, Kuriyama K, Tanabe W, et al. Endoscopic stent placement above the intact sphincter of Oddi for biliary strictures after living donor liver transplantation. J Gastroenterol 2013;48: 1097-1104. doi: 10.1007/s00535-012-0705-x.

[53] Holt AP, Thorburn D, Mirza D, Gunson B, Wong T, Haydon G. A prospective study of standardized nonsurgical therapy in the management of biliary anastomotic strictures complicating liver transplantation. Transplantation 2007;84:857-863. doi: 10.1097/01.tp.0000282805.33658.ce.

[54] Weber A, Prinz C, Gerngross C, Ludwig L, Huber W, Neu B, et al. Long-term outcome of endoscopic and/or percutaneous transhepatic therapy in patients with biliary stricture after orthotopic liver transplantation. J Gastroenterol 2009:44:1195-1202. doi: 10.1007/s00535-009-0123-x.

[55] Wang AY, Sauer BG, Behm BW, Ramanath M, Cox DG, Ellen KL, et al. Singleballoon enteroscopy effectively enables diagnostic and therapeutic retrograde cholangiography in patients with surgically altered anatomy. Gastrointest Endosc 2010;71:641-649. doi: 10.1016/j.gie.2009.10.051.

[56] Shah RJ, Smolkin M, Yen R, Ross A, Kozarek RA, Howell DA, et al. A multicenter, U.S. experience of single-balloon, double-balloon, and rotational overtube-assisted enteroscopy ERCP in patients with surgically altered pancreaticobiliary anatomy (with video). Gastrointest Endosc 2013;77:593600. doi: 10.1016/j.gie.2012.10.015.

[57] op den Dries S, Westerkamp AC, Karimian N, Gouw AS, Bruinsma BG, Markmann JF, et al. Injury to peribiliary glands and vascular plexus before liver transplantation predicts formation of non-anastomotic biliary strictures. J Hepatol 2014;60:1172-1179. doi: 10.1016/j.jhep.2014.02.010.

[58] Hansen $T$, Hollemann $D$, Pitton MB, Heise M, Hoppe-Lotichius $M$, Schuchmann $\mathbf{M}$, et al. Histological examination and evaluation of donor bile ducts received during orthotopic liver transplantation-a morphological clue to ischemic-type biliary lesion? Virchows Arch 2012;461:41-48. doi: $10.1007 / \mathrm{s} 00428-012-1245-8$.
[59] Hüsing A, Reinecke H, Cicinnati VR, Beckebaum S, Wilms C, Schmidt HH, et al. Paclitaxel-eluting balloon dilation of biliary anastomotic stricture after liver transplantation. World J Gastroenterol 2015;21:977-981. doi: 10. 3748/wjg.v21.i3.977.

[60] Farouk M, Branum GD, Watters CR, Cucchiaro G, Helms M, McCann R, et al. Bile compositional changes and cholesterol stone formation following orthotopic liver transplantation. Transplantation 1991;52:727-730. doi: 10. 1097/00007890-199110000-00028.

[61] Karimian N, Op den Dries S, Porte RJ. The origin of biliary strictures after liver transplantation: is it the amount of epithelial injury or insufficient regeneration that counts? J Hepatol 2013;58:1065-1067. doi: 10.1016/j. jhep.2013.02.023.

[62] Graziadei IW, Schwaighofer $H$, Koch R, Nachbaur K, Koenigsrainer A, Margreiter $\mathrm{R}$, et al. Long-term outcome of endoscopic treatment of biliary strictures after liver transplantation. Liver Transpl 2006;12:718725. doi: $10.1002 /$ It.20644

[63] Guichelaar MM, Benson JT, Malinchoc M, Krom RA, Wiesner RH, Charlton MR. Risk factors for and clinical course of non-anastomotic biliary strictures after liver transplantation. Am J Transplant 2003;3:885-890. doi: 10. 1034/j.1600-6143.2003.00165.x.

[64] Park JS, Kim MH, Lee SK, Seo DW, Lee SS, Han J, et al. Efficacy of endoscopic and percutaneous treatments for biliary complications after cadaveric and living donor liver transplantation. Gastrointest Endosc 2003;57: 78-85. doi: $10.1067 / \mathrm{mge} .2003 .11$.

[65] Koneru B, Sterling MJ, Bahramipour PF. Bile duct strictures after liver transplantation: a changing landscape of the Achilles' heel. Liver Transpl 2006; 12:702-704. doi: 10.1002/It.20753.

[66] Arain MA, Attam R, Freeman ML. Advances in endoscopic management of biliary tract complications after liver transplantation. Liver Transpl 2013;19: 482-498. doi: 10.1002/lt.23624.

[67] Hampe T, Dogan A, Encke J, Mehrabi A, Schemmer P, Schmidt J, et al. Biliary complications after liver transplantation. Clin Transplant 2006;20 Suppl 17: 93-96. doi: 10.1111/j.1399-0012.2006.00607.x.

[68] Shin M, Joh JW. Advances in endoscopic management of biliary complications after living donor liver transplantation: Comprehensive review of the literature. World J Gastroenterol 2016;22:6173-6191. doi: 10.3748/wjg. v22.i27.6173.

[69] Kim JH, Lee SK, Kim MH, Song MH, Park DH, Kim SY, et al. Percutaneous transhepatic cholangioscopic treatment of patients with benign bilio-enteric anastomotic strictures. Gastrointest Endosc 2003;58:733-738. doi: 10. 1016/s0016-5107(03)02144-8.

[70] Balderramo D, Sendino O, Miquel R, de Miguel CR, Bordas JM, Martinez-Palli $\mathrm{G}$, et al. Prospective evaluation of single-operator peroral cholangioscopy in liver transplant recipients requiring an evaluation of the biliary tract. Liver Transpl 2013;19:199-206. doi: 10.1002/lt.23585.

[71] Verdonk RC, Buis CI, van der Jagt EJ, Gouw AS, Limburg AJ, Slooff MJ, et al. Nonanastomotic biliary strictures after liver transplantation, part 2: Management, outcome, and risk factors for disease progression. Liver Transpl 2007; 13:725-732. doi: 10.1002/It.21165.

[72] Scanga AE, Kowdley KV. Management of biliary complications following orthotopic liver transplantation. Curr Gastroenterol Rep 2007;9:31-38. doi: $10.1007 / \mathrm{s} 11894-008-0018-7$.

[73] Sheng R, Sammon JK, Zajko AB, Campbell WL. Bile leak after hepatic transplantation: cholangiographic features, prevalence, and clinical outcome. Radiology 1994;192:413-416. doi: 10.1148/radiology.192.2.8029406.

[74] Akamatsu N, Sugawara Y, Hashimoto D. Biliary reconstruction, its complications and management of biliary complications after adult liver transplantation: a systematic review of the incidence, risk factors and outcome. Transpl Int 2011;24:379-392. doi: 10.1111/j.1432-2277.2010.01202.x.

[75] Kochhar G, Parungao JM, Hanouneh IA, Parsi MA. Biliary complications following liver transplantation. Send to World J Gastroenterol 2013;19:28412846. doi: 10.3748/wjg.v19.i19.2841.

[76] Park TY, Lee SK, Nam K, Oh D, Song TJ, Park DH, et al. Spontaneous hemobilia after liver transplantation: Frequency, risk factors, and outcome of endoscopic management. J Gastroenterol Hepatol 2017;32:583-588. doi: 10.1111/jgh.13497.

[77] Koneru B, Zajko AB, Sher L, Marsh JW, Tzakis AG, Iwatsuki S, et al. Obstructing mucocele of the cystic duct after transplantation of the liver. Surg Gynecol Obstet 1989;168:394-396.

[78] Shuhart MC, Kowdley KV, McVicar JP, Rohrmann CA, McDonald MF, Wadland DW, et al. Predictors of bile leaks after T-tube removal in orthotopic liver transplant recipients. Liver Transpl Surg 1998;4:62-70. doi: 10.1002/It. 500040109.

[79] Morelli J, Mulcahy HE, Willner IR, Baliga P, Chavin KD, Patel R, et al. Endoscopic treatment of post-liver transplantation biliary leaks with stent placement across the leak site. Gastrointest Endosc 2001;54:471-475. doi: 10. 1067/mge.2001.117762.

[80] Sherman S, Shaked A, Cryer HM, Goldstein LI, Busuttil RW. Endoscopic management of biliary fistulas complicating liver transplantation and 
other hepatobiliary operations. Ann Surg 1993;218:167-175. doi: 10 . 1097/00000658-199308000-00008.

[81] Nasr JY, Slivka A. Endoscopic approach to the post liver transplant patient. Gastrointest Endosc Clin N Am 2013;23:473-481. doi: 10.1016/j.giec. 2012.12.014.

[82] Dumonceau JM, Tringali A, Blero $D$, Devière J, Laugiers R, Heresbach $D$, et al. Biliary stenting: indications, choice of stents and results: European Society of Gastrointestinal Endoscopy (ESGE) clinical guideline. Endoscopy 2012;44:277-298. doi: 10.1055/s-0031-1291633.

[83] Phillips MS, Bonatti H, Sauer BG, Smith L, Javaid M, Kahaleh M, et al. Elevated stricture rate following the use of fully covered self-expandable metal biliary stents for biliary leaks following liver transplantation. Endoscopy 2011;43:512-517. doi: 10.1055/s-0030-1256389.

[84] Luigiano C, Bassi M, Ferrara F, Fabbri C, Ghersi S, Morace C, et al. Placement of a new fully covered self-expanding metal stent for postoperative biliary strictures and leaks not responding to plastic stenting. Surg Laparosc Endosc Percutan Tech 2013;23:159-162. doi: 10.1097/SLE. Ob013e318278c201.

[85] Attam R, Leslie D, Freeman M, Ikramuddin S, Andrade R. EUS-assisted, fluoroscopically guided gastrostomy tube placement in patients with Roux-en-Y gastric bypass: a novel technique for access to the gastric remnant. Gastrointest Endosc 2011;74:677-682. doi: 10.1016/j.gie. 2011.05.018.

[86] Schreiner MA, Chang L, Gluck M, Irani S, Gan SI, Brandabur J], et al. Laparoscopy-assisted versus balloon enteroscopy-assisted ERCP in bariatric post-Roux-en-Y gastric bypass patients. Gastrointest Endosc 2012;75: 748-756. doi: 10.1016/j.gie.2011.11.019.

[87] Saab S, Martin P, Soliman GY, Machicado GA, Roth BE, Kunder G, et al. Endoscopic management of biliary leaks after T-tube removal in liver transplant recipients: nasobiliary drainage versus biliary stenting. Liver Transpl 2000;6:627-632. doi: 10.1053/jlts.2000.8200.

[88] Sheng R, Ramirez CB, Zajko AB, Campbell WL. Biliary stones and sludge in liver transplant patients: a 13-year experience. Radiology 1996;198:243247. doi: 10.1148/radiology.198.1.8539387.

[89] Spier BJ, Pfau PR, Lorenze KR, Knechtle SJ, Said A. Risk factors and outcomes in post-liver transplantation bile duct stones and casts: A casecontrol study. Liver Transpl 2008;14:1461-1465. doi: 10.1002/lt.21511.

[90] Gor NV, Levy RM, Ahn J, Kogan D, Dodson SF, Cohen SM. Biliary cast syndrome following liver transplantation: Predictive factors and clinical outcomes. Liver Transpl 2008;14:1466-1472. doi: 10.1002/It.21492.

[91] Cillo U, Burra P, Norberto L, D'Amico D. Bile duct stones and casts after liver transplantation: Different entities but similar prevention strategy? Liver Transpl 2008;14:1400-1403. doi: 10.1002/It.21628.

[92] Waldram R, Williams R, Calne RY. Bile composition and bile cast formation after transplantation of the liver in man. Transplantation 1975;19:382-387. doi: 10.1097/00007890-197505000-00004

[93] Lisotti A, Fusaroli P, Caletti G. Role of endoscopy in the conservative management of biliary complications after deceased donor liver transplantation. World J Hepatol 2015;7:2927-2932. doi: 10.4254/wjh.v7.i30.2927.

[94] Lisotti A, Caponi A, Gibiino G, Muratori R. Safety and efficacy of extracorporeal shock-wave lithotripsy in the management of biliary stones after orthotopic liver transplantation. Dig Liver Dis 2015;47:817-818. doi: 10. 1016/j.dld.2015.06.001.

[95] Krok KL, Cárdenas A, Thuluvath PJ. Endoscopic management of biliary complications after liver transplantation. Clin Liver Dis 2010;14:359-371. doi: 10.1016/j.cld.2010.03.008.

[96] Voigtländer T, Negm AA, Strassburg CP, Lehner F, Manns MP, Lankisch TO. Biliary cast syndrome post-liver transplantation: risk factors and outcome. Liver Int 2013;33:1287-1292. doi: 10.1111/liv.12181.

[97] Memeo R, Piardi T, Sangiuolo F, Sommacale D, Pessaux P. Management of biliary complications after liver transplantation. World J Hepatol 2015; 7 2890-2895. doi: 10.4254/wjh.v7.i29.2890.
[98] Shah JN, Haigh WG, Lee SP, Lucey MR, Brensinger CM, Kochman ML, et al. Biliary casts after orthotopic liver transplantation: clinical factors, treatment, biochemical analysis. Am J Gastroenterol 2003;98:1861-1867. doi: $10.1111 / j .1572-0241.2003 .07617 . x$.

[99] Said A, Safdar N, Lucey MR, Knechtle SJ, D'Alessandro A, Musat A, et al. Infected bilomas in liver transplant recipients, incidence, risk factors and implications for prevention. Am J Transplant 2004;4:574-582. doi: 10 . 1111/j.1600-6143.2004.00374.x.

[100] Manzarbeitia C, Jonsson J, Rustgi V, Oyloe VK, Olson L, Hefter L, et al. Management of hemobilia after liver biopsy in liver transplant recipients. Transplantation 1993;56:1545-1547.

[101] Zajko AB, Bennett MJ, Campbell WL, Koneru B. Mucocele of the cystic duct remnant in eight liver transplant recipients: findings at cholangiography, CT, and US. Radiology 1990;177:691-693. doi: 10.1148/radiology.177.3. 2243970.

[102] Chatterjee S, Das D, Hudson M, Bassendine MF, Scott J, Oppong KE, et al. Mucocele of the cystic duct remnant after orthotopic liver transplant: a problem revisited. Exp Clin Transplant 2011;9:214-216.

[103] Torres V, Martinez N, Lee G, Almeda J, Gross G, Patel S, et al. How do we manage post-OLT redundant bile duct? World J Gastroenterol 2013;19: 2501-2506. doi: 10.3748/wjg.v19.i16.2501.

[104] Millonig G, Buratti T, Graziadei IW, Schwaighofer H, Orth D, Margreiter R, et al. Bactobilia after liver transplantation: frequency and antibiotic susceptibility. Liver Transpl 2006;12:747-753. doi: 10.1002/lt.20711.

[105] Stapleton GN, Hickman R, Terblanche J. Blood supply of the right and left hepatic ducts. Br J Surg 1998;85:202-207. doi: 10.1046/j.1365-2168. 1998.00511.x.

[106] Qian YB, Liu CL, Lo CM, Fan ST. Risk factors for biliary complications after liver transplantation. Arch Surg 2004;139:1101-1105. doi: 10.1001/archsurg.139.10.1101.

[107] Vellar ID. The blood supply of the biliary ductal system and its relevance to vasculobiliary injuries following cholecystectomy. Aust N Z J Surg 1999;69: 816-820. doi: 10.1046/j.1440-1622.1999.01702.x.

[108] Wan P, Yu X, Xia Q. Operative outcomes of adult living donor liver transplantation and deceased donor liver transplantation: a systematic review and meta-analysis. Liver Transpl 2014;20:425-436. doi: 10.1002/It. 23836.

[109] Takatsuki M, Eguchi S, Kawashita Y, Kanematsu T. Biliary complications in recipients of living-donor liver transplantation. J Hepatobiliary Pancreat Surg 2006;13:497-501. doi: 10.1007/s00534-005-1082-0.

[110] Tashiro H, Itamoto T, Sasaki T, Ohdan H, Fudaba Y, Amano H, et al. Biliary complications after duct-to-duct biliary reconstruction in living-donor liver transplantation: causes and treatment. World J Surg 2007;31:2222-2229. doi: $10.1007 / \mathrm{s} 00268-007-9217-x$.

[111] Lin TS, Concejero AM, Chen CL, Chiang YC, Wang CC, Wang SH, et al. Routine microsurgical biliary reconstruction decreases early anastomotic complications in living donor liver transplantation. Liver Transpl 2009;15: 1766-1775. doi: 10.1002/lt.21947.

[112] Bourgeois N, Deviére J, Yeaton P, Bourgeois F, Adler M, Van De Stadt J, et al. Diagnostic and therapeutic endoscopic retrograde cholangiography after liver transplantation. Gastrointest Endosc 1995;42:527-534. doi: 10. 1016/s0016-5107(95)70005-6.

[113] Ito T, Kiuchi T, Egawa H, Kaihara S, Oike F, Ogura $Y$, et al. Surgery-related morbidity in living donors of right-lobe liver graft: lessons from the first 200 cases. Transplantation 2003;76:158-163. doi: 10.1097/01.TP. 0000072372.42396 .47$.

[114] Lo CM. Complications and long-term outcome of living liver donors: a survey of 1,508 cases in five Asian centers. Transplantation 2003;75: S12-S15. doi: 10.1097/01.TP.0000046534.45645.47.

[115] Londoño MC, Balderramo D, Cárdenas A. Management of biliary complications after orthotopic liver transplantation: the role of endoscopy. World J Gastroenterol 2008;14:493-497. doi: 10.3748/wjg.14.493. 